comparison of C-peptide, pro-insulin and insulin. 7 Clin Endocrino Metab $1977 ; 45: 441-5$.

20 Zubrod CG, Eversole SL, Dana GW. Amelioration of diabetes and striking rarity of acidosis in patients with Kimmelstiel-Wilson lesions. N Engl f Med 1951 ;245:518-25.

21 Runyan JW, Hurwitz D, Robbins SL. Effect of Kimmelstiel-Wilson syndrome on insulin requirements in diabetes. N Engl f Med 1955;252 388-91.

22 Epstein FH, Zupa VJ. Clinical correlates of the Kimmelstiel-Wilson lesion. N Engl f Med 1956;254:896-900.

23 Kalliomäki JL, Markkanen TK, Sourander LB. Correlation between insulin requirement and renal retention in diabetic nephropathy. Acto Med Scand 1960;166:423-4.

24 Hatch FE, Parrish AE. Apparent remission of a severe diabetic on developing the Kimmelstiel-Wilson syndrome. Ann Intern Med 1961; 54:544-9.

25 Thomsen AC. The kidney in diabetes mellitus. Copenhagen: Munksgaard, $1965: 220$.

${ }^{26}$ Hampers CL, Soeldner JS, Doak PB, Merrill JP. Effect of chronic renal failure and haemodialysis on carbohydrate metabolism. 7 Clin Invest $1966 ; 45: 1719-31$.

27 Lowrie EG, Soeldner JS, Hampers CL, Merrill JP. Glucose metabolism and insulin secretion in uremic, prediabetic, and normal subjects. F Lab Clin Med 1970;76:603-15.

28 Unger R. Meticulous control of diabetes: benefits, risks, and precautions. Diabetes $1982 ; 31: 479-83$.

(Accepted 31 fanuary 1984)

\title{
Psychosocial stress in pregnancy and its relation to low birth weight
}

\author{
RICHARD W NEWTON, LINDA P HUNT
}

\begin{abstract}
The relation of low birth weight to psychosocial stress in pregnancy was examined using a life events inventory and a state anxiety index. Two hundred and fifty women were randomly selected and interviewed three times during pregnancy and shortly after delivery. Twenty six were excluded. Of the remaining 224 women, nine miscarried, 195 had healthy term babies, and 20 gave birth to babies that were either premature or of low birth weight at term.

Low birth weight and prematurity were significantly associated with objective major life events but not state anxiety. The occurrence of objective major life events in the third trimester may be important in precipitating preterm labour. Cigarette smoking was the best predictor and objective major life events the second best predictor of low birth weight. The result was not dependent on social class.
\end{abstract}

These findings suggest that cigarette smoking may be an important mediator of stress on the fetus. Antenatal care should take greater account of stress in pregnancy, and social support systems should be evaluated.

\section{Introduction}

Previous work on stress in pregnancy has often incorporated serious methodological errors. Maternal factors as diverse as a marginal placenta and pre-eclampsia and infant factors as diverse as jaundice and cord around the neck have been used to define adverse outcome of pregnancy. ${ }^{1}$ In one study infant abnormalities ranged from hydrocephalus to a bruised nose." This failure to categorise abnormality prevents sensible inter-

Booth Hall Children's Hospital, Manchester M9 2AA

RICHARD W NEWTON, MD, MRCP, consultant paediatric neurologist

Stopford Building, University of Manchester, Manchester 13 LINDA P HUNT, MSC, MIS, lecturer, faculty of medicine computational group

Correspondence to: $\mathrm{Dr} \mathrm{R}$ W Newton. pretation of the results. Studies have also generally failed to consider the importance of psychosocial stress relative to factors known to be associated with low birth weight, such as social class and cigarette smoking, though there have been notable exceptions. ${ }^{3}$ Retrospective studies have often allowed the possible bias of results by "effort after meaning," a term that implies that women experiencing an adverse outcome of pregnancy may make a conscious effort to explain this by blaming a particular life event that has happened to them.

Because of these methodological problems in previous studies we carried out a prospective study of an unselected population of women who were interviewed at least twice during pregnancy by a single interviewer (RWN). The number, nature, and subjective effect of any life events were recorded, the outcome of pregnancy defined, and the contribution of social class and cigarette smoking considered. We report here our results.

\section{Patients and methods}

The study population was randomly selected from women booking into St Mary's Hospital, Manchester, for their antenatal care. Hospital Activity Analysis showed that $86^{\circ}$ of babies of low birth weight were booked deliveries. To avoid language difficulties only women born in the United Kingdom were interviewed, irrespective of racial origin; $95^{\circ}$ o were white.

Assuming a prevalence of babies of low birth weight of 8-10\% and a prevalence of major life events similar to that recorded in our previous, retrospective study, ${ }^{4}$ we selected a population of 250 to give a group of about 20 babies of low birth weight $(\leqslant 2500 \mathrm{~g})$ and, probably, a significant result.

Patients were interviewed at their initial booking visit, at about 30 weeks' gestation, when possible between 37 and 40 weeks' gestation, and shortly after delivery. Age, marital state, husband's occupation, number of people per room (as defined by the Office of Population Censuses and Surveys ${ }^{5}$ ) at home, obstetric history, and smoking habit were recorded. The modified life events inventory used in the retrospective study ${ }^{4}$ was presented at each interview and the experience and timing of any life event during pregnancy noted. Patients were also asked to complete Spielberger's state anxiety index ${ }^{6}$ according to how they felt "at that moment in the antenatal clinic"; they also completed the index in relation to any major life event experienced according to how they had "felt about it at the time."

The state anxiety index is self administered and contains 20 items, each scored on a scale of 1 to 4 . The four categories are: 1 , not at all; 2 , somewhat; 3 , moderately so; and 4 , very much so. Half of the 
items are worded so that a score of 4 indicates a high level of anxiety (for example, I am tense) whereas half are worded so that a rating of 1 indicates a high level of anxiety (for example, I feel pleasant). When completed the index is hand scored; the range of possible scores is $20-80$.

Interviewing of the 250 women was completed over an 18 month period from September 1980 to April 1982.

\section{DEFINITIONS}

When originally standardised in a population of pregnant women each life event on the modified life events inventory was given a score or weight on a 1-100 scale according to the amount of "turmoil, disturbance, or upheaval" it would cause were it to occur. "Getting married" scores arbitrarily as $\mathbf{5 0}$ to establish a reference point halfway up the scale. The following definitions were used in this study:

Major life events-Events experienced with a weight of 60 or more on the modified life events inventory.

Objective major life events-A major life event whose occurrence could be confirmed by a disinterested third party-that is, one that is a fact and uncoloured by the feelings of the subject or interviewer (for example, husband becoming unemployed).

Self rated major life events-A major life event that has apparently caused considerable anxiety to the person experiencing it. If the score on the state anxiety index for a particular major life event was 50 or the score on the index in relation to the major life event was $50 \%$ greater than the score on the index for the interview in the antenatal clinic, then the major life event was regarded as a self rated major life event.

Interview weight scores represent not just major life events but are the sum of the weight scores of all life events experienced in the period covered by the interview.

The appendix lists the major life events on the inventory and indicates which are considered to be objective.

\section{STATISTICAL ANALYSIS}

A two tailed Student's $t$ test was used to compare means of measurements from two independent samples. A Mann-Whitney $U$ test was used to compare measurements that were skewed-for example, numbers of life events-and a Kruskal-Wallis one way analysis of variance when there were more than two groups-for example, life event weight scores in three smoking groups. Chi squared tests were used to compare frequency distributions, with Fisher's exact test for two by two tables with small expected frequencies. Multivariate analysis used a binomial logit model ${ }^{7}$ to search for best predictors of low birth weight. A forward stepwise method was used, choosing as best predictor at each step the variable that gave the most significant change in maximum likelihood $\chi^{2}$.

Statistics were computed using the statistical package for the social sciences. ${ }^{8}$ This gives median values, which are interpolated even though some of the data are discrete. Nevertheless, the decimal figure has been retained to give a better representation of the distribution of the data.

To analyse the effect of timing of life events in pregnancy matched controls were selected from the mothers of term babies for each woman who delivered a preterm baby or one of low birth weight or small for gestational age. Controls were matched for social class and cigarette smoking in all cases and then as far as possible for age, gravidity, parity, number of years of marriage, and number of people per room at home.

\section{Results}

Of the 250 women in the study, 26 had to be excluded. Follow up interviews were omitted through human error in 12; eight moved away; two were found subsequently not to be pregnant; one declined further interview; two had terminations at 17 weeks for anencephaly or spina bifida; and one baby was stillborn at 34 weeks with anencephaly, spina bifida, and exomphalos, which had been noted on an early scan. Subsequent analysis refers to the remaining 224 women, of whom nine miscarried, 195 gave birth to healthy babies at term, and 20 gave birth to either preterm babies or babies of low birth weight at term. One preterm baby weighed $3150 \mathrm{~g}$ and was therefore excluded from the low birthweight group. The tables refer to 19 pregnancies that resulted in low birthweight babies, and 12 that resulted in preterm babies.

Nineteen pregnancies led to the birth of 21 low birthweight babies. Four such babies were from multiple pregnancies, four were delivered electively before term, seven were delivered after spontaneous onset of labour before term, and eight showed growth retardation at term. (One set of twins were delivered before term and are therefore counted twice above.) These figures are comparable with previous published data on low birth weight. ${ }^{8}$ One set of triplets was excluded from all subsequent analysis, but as there was a set of twins in both the group of low birthweight (preterm) babies and the group of term baoies these were retained.

There was no significant difference in age, gravidity, or parity between mothers of babies weighing more than $2500 \mathrm{~g}$ at term and those of low birthweight or preterm babies (table I). Comparison with Hospital Activity Analysis figures for St Mary's Hospital in 1980, however, showed an overrepresentation of primigravid women in the study group ( $46 \% v 31 \%$ in the Hospital Activity Analysis), representing either selection bias or a change in birth characteristics over the previous two years. No significant difference was found in social class distribution between the study group and a random selection of 300 women delivering at the hospital over the same period. Table II shows the social class distribution and smoking habit in the study group. There were significantly more smokers among single women and those in classes IV and $\mathrm{V}$ than among those in classes I and II ( $\chi^{2}$ after recombination $=27 \cdot 40, p<0.001$ ).

Table III compares numbers of total, objective, and self rated major life events according to birth weight and duration of gestation. The most significant associations were noted between premature delivery and low birth weight and the experience during pregnancy of objective major life events.

Table IV records the number of women experiencing objective major life events at different stages of pregnancy among those who

TABLE I-Age, parity, and gravidity of mothers according to gestational age and birth weight

\begin{tabular}{|c|c|c|c|}
\hline & $\begin{array}{c}\text { Term } \\
(>2500 \mathrm{~g}) \\
(\mathrm{n}=195)\end{array}$ & $\begin{array}{c}\text { Low birth weight } \\
\qquad \begin{array}{c}(\mathrm{N}=1900 \mathrm{~g}) \\
(\mathrm{n}=19)\end{array}\end{array}$ & $\begin{array}{c}\text { Preterm } \\
(<37 \text { weeks }) \\
(\mathrm{n}=12)\end{array}$ \\
\hline $\begin{array}{l}\text { Age (years): } \\
\text { Mean } \\
\text { SD } \\
\text { Range }\end{array}$ & $\begin{array}{c}25 \cdot 6 \\
5 \cdot 2 \\
15-41\end{array}$ & $\begin{array}{c}26 \cdot 2 \\
4 \cdot 5 \\
18-37\end{array}$ & $\begin{array}{c}26 \cdot 9 \\
4 \cdot 7 \\
20-37\end{array}$ \\
\hline $\begin{array}{l}\text { Parity: } \\
\text { Mean } \\
\text { Range } \\
\text { No }(\%) \text { primigravid }\end{array}$ & $\begin{array}{c}0.9 \\
0-6 \\
87(45)\end{array}$ & $\begin{array}{l}0.6 \\
0-2 \\
10(53)\end{array}$ & $\begin{array}{l}0 \cdot 7 \\
0-2 \\
6(50)\end{array}$ \\
\hline
\end{tabular}

TABLE iI-Study group by social class and marital state, showing smoking characteristics (figures are numbers $(\%)$ of women in each social class)

\begin{tabular}{|c|c|c|c|c|c|c|}
\hline & \multicolumn{6}{|c|}{ Social class (Registrar General's classification) } \\
\hline & I & II & III & IV & $\mathbf{V}$ & $\begin{array}{c}\text { Single } \\
\text { (unsupported) }\end{array}$ \\
\hline $\begin{array}{l}\text { Total group }(n=224) \\
\text { Non-smokers }(n=156) \\
\text { Smokers: }\end{array}$ & $\begin{array}{l}22(10) \\
21(100)\end{array}$ & $\begin{array}{l}49(22) \\
41(84)\end{array}$ & $\begin{array}{l}64(29) \\
46(73)\end{array}$ & $\begin{array}{r}13(6) \\
9(75)\end{array}$ & $\begin{array}{l}32(14) \\
20(62)\end{array}$ & $\begin{array}{l}44(20) \\
19(45)\end{array}$ \\
\hline $\begin{array}{l}\text {-10/day }(n=32) \\
>10 / \text { day }(n=31)\end{array}$ & & $\begin{array}{l}6(12) \\
2(4)\end{array}$ & $\begin{array}{r}7(11) \\
10(16)\end{array}$ & $3(25)$ & $\begin{array}{l}5(16) \\
7(22)\end{array}$ & $\begin{array}{r}14(33) \\
9(21)\end{array}$ \\
\hline
\end{tabular}

Smoking habit was not recorded in five women who miscarried (one each from classes I, III, and IV, and two single women).

TABLE III-Numbers of total, objective, and self rated major life events recorded during pregnancy according to birth weight and gestational age (triplets excluded) (figures are medians (and ranges))

\begin{tabular}{|c|c|c|c|c|}
\hline & \multicolumn{2}{|c|}{ Birth weight } & \multicolumn{2}{|c|}{ Gestational age } \\
\hline & $\begin{array}{l}2500 \mathrm{~g} \\
(\mathrm{n}=18)\end{array}$ & $\begin{array}{l}>2500 \mathrm{~g} \\
(\mathrm{n}=196)\end{array}$ & $\begin{array}{c}37 \text { weeks } \\
(n=12)\end{array}$ & $\begin{array}{l}\geqslant 37 \text { weeks } \\
(n=203)\end{array}$ \\
\hline Total & \multicolumn{2}{|c|}{$1.50(0-6)$ NS $0.83(0-6)$} & \multicolumn{2}{|c|}{$\begin{array}{c}1.67(0-6) \\
p=0.046\end{array}$} \\
\hline Objective & \multicolumn{2}{|c|}{$\begin{aligned} 1.21(0-4) & 0.37(0-4) \\
p & =0.004\end{aligned}$} & \multicolumn{2}{|c|}{$\begin{aligned} 1.50(0-3) & 0.38(0-4) \\
\mathrm{p} & =0.001\end{aligned}$} \\
\hline Self rated & $0.90(0-6)$ & $0.32(0-5)$ & $1 \cdot 10(0-6)$ & $\begin{array}{l}0.33(0-5) \\
26\end{array}$ \\
\hline
\end{tabular}

Significance assessed with Mann-Whitney $U$ test. 
TABLE IV-Incidence of objective major life events (none, or one or more) according to stage of pregnancy in women in study and matched controls (figures are numbers $(\%)$ of women (triplets excluded))

\begin{tabular}{|c|c|c|c|c|c|c|}
\hline & \multicolumn{2}{|c|}{$0-13$ weeks } & \multicolumn{2}{|c|}{ 14-26 weeks } & \multicolumn{2}{|c|}{$27-36$ weeks } \\
\hline & 0 & $\geqslant 1$ & 0 & $\geqslant 1$ & 0 & $\geqslant 1$ \\
\hline$\underset{(n=195)}{\operatorname{Term}}(>2500 \mathrm{~g})$ & $137(70)$ & $58(30)$ & $187(96)$ & $8(4)$ & $157(81)$ & $38(19)]$ \\
\hline $\begin{array}{l}\text { Preterm babies }(n=11) \\
\text { Controls }(n=11)\end{array}$ & $\begin{array}{l}7(64) \\
8(73)\end{array}$ & $\begin{array}{l}4(36) \\
3(27)\end{array}$ & $\begin{array}{l}10(91) \\
11(100)\end{array}$ & $\begin{array}{l}1(9) \\
0 \stackrel{(-)}{(-)}\end{array}$ & $\begin{array}{r}3(27) \\
10(91)\end{array}$ & $\left.\begin{array}{l}8(73) \\
1(9)\end{array}\right]+$ \\
\hline $\begin{array}{l}\text { Low birthweight babies } \\
(n=18) \\
\text { Controls }(n=18)\end{array}$ & $\begin{array}{l}13(72) \\
12(67)\end{array}$ & $\begin{array}{l}5(28) \\
6(33)\end{array}$ & $\begin{array}{l}15(83) \\
17(94)\end{array}$ & $\begin{array}{l}3(17) \\
1(6)\end{array}$ & $\begin{array}{r}8(44) \\
13(72)\end{array}$ & $\left.\begin{array}{r}10(56) \\
3(28)\end{array}\right]$ \\
\hline $\begin{array}{l}\text { Babies small for } \\
\text { gestational age }(n=10) \\
\text { Controls }(n=10)\end{array}$ & $\begin{array}{l}8(80) \\
5(50)\end{array}$ & $\begin{array}{l}2(20) \\
5(50)\end{array}$ & $\begin{array}{l}8(80) \\
9(90)\end{array}$ & $\begin{array}{l}2(20) \\
1(10)\end{array}$ & $\begin{array}{l}6(60) \\
7(70)\end{array}$ & $\begin{array}{l}4(40) \\
3(30)\end{array}$ \\
\hline
\end{tabular}

Significance $\left(x^{2}\right.$ test): ${ }^{*} p<0.001 ;+p<0.005 ; \ddagger p<0.05 ; \S p<0.01$.

TABLE V-Numbers of major life events according to social class (includes women who miscarried) (figures are medians (and ranges))

\begin{tabular}{|c|c|c|c|c|c|c|}
\hline & \multicolumn{6}{|c|}{ Socioeconomic group $(n=224)$} \\
\hline & $\begin{array}{c}\mathrm{I} \\
(\mathrm{n}=22)\end{array}$ & $\underset{(n=49)}{\text { II }}$ & $\underset{(n=64)}{\text { III }}$ & $\underset{(n=13)}{I V}$ & $\begin{array}{c}\mathrm{V} \\
(\mathrm{n}=32)\end{array}$ & $\underset{(\mathrm{n}=44)}{\text { Single }}$ \\
\hline $\begin{array}{l}\text { Total* } \\
\text { Objective } \\
\text { Self rated }\end{array}$ & $\begin{array}{l}0.42(0-2) \\
0.15(0-2) \\
0.15(0-2)\end{array}$ & $\begin{array}{l}0.44(0-4) \\
0.27(0-2) \\
0.32(0-3)\end{array}$ & $\begin{array}{l}0.75(0-6) \\
0.34(0-4) \\
0.30(0-5)\end{array}$ & $\begin{array}{l}0.88(0-3) \\
0.43(0-3) \\
0.31(0-3)\end{array}$ & $\begin{array}{l}1.38(0-6) \\
0.93(0-4) \\
0.30(0-6)\end{array}$ & $\begin{array}{l}1.43(0-5) \\
0.88(0-3) \\
0.86(0-5)\end{array}$ \\
\hline
\end{tabular}

*Significance of result (Kruskal-Wallis test): ${ }^{*} p=0.0006 ;+p=0.0017 ; \ddagger p=0.0364$. pregnancy and relevant biological factors were useful predictors of low birth weight in the study population. The biological factors considered were age less than 20 ; single state; two or more previous miscarriages; primigravid state; pre-eclampsia; social classes IV and $\mathrm{V}$; and cigarette smoking. The number of people per room and the state anxiety scores recorded at each interview were also considered. Analysis indicated that the most important predictor of low birth weight in the study population was cigarette smoking; the second most important predictor was an objective major life event, although this did not significantly improve the model.

The objective major life events recorded most commonly by the women in the low birthweight and preterm groups were unemployment or a considerable decrease in income (three women) and family illness ( 11 women). These were recorded by 28 and 53 women, respectively, who gave birth to babies at term.

Table VI shows that the mean birth weight of babies born to mothers who had experienced at least two objective major life events during their pregnancies was considerably lower than that of those experiencing none. The mean birth weight of babies of mothers experiencing one objective major life event lay intermediately between the two figures. The same rank order for mean birth weight applied to both smoking and non-smoking women, though the observed differences in these groups were not significant.

\section{Discussion}

This prospective study has confirmed the finding that there is a significant association between the experience of major life events in pregnancy and preterm delivery. ${ }^{4}$ This association

TABLE VI-Mean birth weights $(g)$ of babies according to number of objective major life events experienced by mothers during pregnancy

\begin{tabular}{|c|c|c|c|c|c|c|c|c|c|}
\hline & \multicolumn{3}{|c|}{ Total } & \multicolumn{3}{|c|}{ Non-smoking } & \multicolumn{3}{|c|}{ Smoking } \\
\hline & $\begin{array}{c}0 \\
(n=116)\end{array}$ & $\left(\begin{array}{c}1 \\
=52)\end{array}\right.$ & $\begin{array}{c}\geqslant 2 \\
(n=44)\end{array}$ & $\begin{array}{c}0 \\
(n=96)\end{array}$ & $\begin{array}{c}1 \\
(n=34)\end{array}$ & $\begin{array}{c}\geqslant 2 \\
(n=22)\end{array}$ & $\begin{array}{c}0 \\
(n=20)\end{array}$ & $\left(\begin{array}{c}1 \\
n=18\end{array}\right)$ & $\begin{array}{c}\geqslant 2 \\
(n=22)\end{array}$ \\
\hline $\begin{array}{l}\text { Mean } \\
\text { SD }\end{array}$ & $\begin{array}{r}3400 \\
500\end{array}$ & $\begin{array}{r}3260 \\
600\end{array}$ & $\begin{array}{r}3120 \\
850\end{array}$ & $\begin{array}{r}3460 \\
470\end{array}$ & $\begin{array}{r}3390 \\
450\end{array}$ & $\begin{array}{r}3360 \\
730\end{array}$ & $\begin{array}{r}3140 \\
540\end{array}$ & $\begin{array}{r}3010 \\
750\end{array}$ & $\begin{array}{r}2890 \\
890\end{array}$ \\
\hline
\end{tabular}

delivered term babies of more than $2500 \mathrm{~g}$, preterm babies, low birthweight babies, and babies who were small for gestational age. Results in matched control groups are also recorded. Objective major life events experienced during the last trimester of pregnancy contributed most to the significant result. This association was not seen in those low birthweight babies who were small for gestational age (eight born at term and two prematurely). Proportionately more women giving birth to babies that were small for gestational age $(70 \%)$ experienced an objective major life event during their pregnancy than did those giving birth to term babies of more than $2500 \mathrm{~g} \mathrm{(42 \% )}$, but this difference was not significant $(p=0.08)$. Comparison of the group giving birth to babies that were small for gestational age with matched controls showed little difference between them.

Consideration of obstetric data showed that of the 20 women who gave birth to either preterm or low birthweight babies at term, six $(30 \%)$ had had a previous abortion or stillbirth, one $(5 \%)$ had had a previous preterm delivery, and four $(20 \%)$ had had preeclampsia; of their 20 matched controls, four $(20 \%)$ had had previous abortions, one (5\%) a previous preterm delivery, and four $(20 \%)$ pre-eclampsia. Of the 195 women delivering babies weighing more than $2500 \mathrm{~g}$ at term, $63(32 \%)$ had had previous abortions, terminations, or stillbirths (4), six $(3 \%)$ had had previous preterm deliveries, and $39(2 \%)$ had had pre-eclampsia. These proportions are notably similar, and obstetric history does not seem to have predetermined low birth weight to any great extent in the study.

Table $\mathrm{V}$ shows how single women and those in social classes IV and $\mathrm{V}$ experienced significantly more major life events during their pregnancies than those in social classes I and II.

A significant positive association was found between the life event weight scores recorded at each interview and the number of cigarettes smoked. The median weight scores for the whole pregnancy in non-smokers, smokers of one to 10 cigarettes a day, and smokers of over 10 cigarettes a day were respectively 33 (range 0-306), 210 (0-815), and 287 (23-677) (Kruskal-Wallis test, $\mathrm{p}=0.002$ ).

Multivariate analysis using a binomial logit model was performed to see whether the experience of objective major life events during is most significant when objective, rather than total or self rated, major life events are considered. A significant association also exists between objective major life events and low birth weight (table III).

The fact that objective major life events have a more significant association with low birth weight than self rated major life events (table III) implies that the actual event is more important than the subjective response to it. This is contrary to what might be expected, but Cobb found that subjects scoring high on a measure of denial reported fewer life events and that this could be an important source of bias in results. ${ }^{10}$ Objective major life events are probably more reliable and valid as measures of external stress as the objectivity is defined and the variability of subjective response removed.

The design of the study made it necessary for us to record life events experienced during the latter part of pregnancy retrospectively (to cover the period between the previous interview and birth), and thus the charge that "effort after meaning" might have biased results may still be made. As the most significant associations noted were with objective major life events, however, the validity of this charge is lessened.

Several known associations were again noted in this study: that of single state and social classes IV and V with heavier smoking, ${ }^{11}$ the experience of more life events ${ }^{412}$ and low birth weight $^{13}$; and that of smoking with low birth weight. ${ }^{1415}$ Before stress in pregnancy can be regarded as partly causal in the aetiology of low birth weight the complex interaction of these variables needs to be unravelled.

Analysis showed that the effect of major life events is not dependent on the social class distribution of the study groups; this was noted previously. ${ }^{4}$ The effect of major life events was also shown to be additional to but not significantly different 
from that of cigarette smoking. The data also suggest that the effects of stress may be additive-that is, the more objective major life events encountered during pregnancy the lower the birth weight is likely to be (table VI)-and that this is true for smoking and non-smoking women.

The effects of stress on the fetus may be mediated in several ways. Women may be induced to smoke more if they smoke already (see results), and catecholamine secretion may compromise placental function, particularly if placental insufficiency already exists. ${ }^{16}$

Table IV indicates how exposure to stress in the last trimester is particularly likely to lead to low birth weight through premature delivery. Uterine smooth muscle has a variable response to secretion of catecholamine during pregnancy that depends on hormonal climate. ${ }^{17}$ As term is approached stress is less likely to promote contractility and may even inhibit it. The timing of exposure to stressful events must also be important in this respect.

The implication of these findings is that a keener assessment of stress experienced by women during their pregnancies should be made and that the possible value of social support systems should be determined.

We thank Mr Christopher Macy, clinical psychologist, South Ranceby Hospital, Lincolnshire, and Professor Eric Stroud, King's College Hospital, London, for their help with the design of the project; and Mrs D Whitworth and Mrs M Richardson for typing the manuscript.

Part of this work was submitted to the University of London as an $\mathrm{MD}$ thesis.

\section{Appendix}

MAJOR LIFE EVENTS ON MODIFIED LIFE EVENTS INVENTORY ${ }^{4}$ (asterisk denotes objective major life event)

*Serious physical illness or injury requiring hospital treatment

*Sudden or serious impairment of vision or hearing

*Immediate family member seriously ill

*Immediate family member attempts suicide

*Immediate family member dies

*Husband dies

*Death of a close friend

*Prolonged ill health in a close relative requiring treatment by a doctor

Increase in number of family arguments (with close family-for example, children)

Undue worry over having a handicapped child

Worry over care of children while in hospital

Your husband uses harsh words to you, is cruel or sarcastic (mental cruelty)

*Your husband is physically cruel to you

Increase in number of arguments with husband

${ }^{*}$ Marital separation

*Divorce

*Extramarital sexual affair
*Your husband is unfaithful

Your boyfriend uses harsh words to you, is cruel or sarcastic (mental cruelty)

*Your boyfriend is physically cruel to you

Increase in number of arguments with your boyfriend

*You split up with your boyfriend

*Your boyfriend is unfaithful

*You are made homeless (or have to sleep in a hostel or sleep rough)

*You are involved in a fight

*You are arrested

*Your husband is arrested

*You have to make a court appearance

*You are convicted of an offence

*Your husband (or head of household) is sent to jail

*Your husband (or head of household) becomes unemployed

*Income decreased substantially (by $25 \%$ )

${ }^{*}$ Getting into debt beyond means of repayment

\section{References}

${ }^{1}$ Gorsuch RL, Key MK. Abnormalities of pregnancy as a function of anxiety and life stress. Psychosom Med 1974;36:352-62.

2 Davids A, Devault $S$. Maternal anxiety during pregnancy and childbirth abnormalities. Psychosom Med 1962;24:464-70.

3 Wolkind S. Pre-natal emotional stress-effects on the foetus. In: Wolkind S, ed. Pregnancy: a psychological and social study. London: Academic Press, $1981: 77-194$.

4 Newton RW, Webster PAC, Binu PS, Maskrey N, Phillips AB. Psychosocial stress in pregnancy and its relation to the onset of premature labour. Br Med F 1979;ii:411-3.

${ }^{5}$ Office of Population Censuses and Surveys. 1981 census, England. ( $\mathrm{H}$ form for private households, section H1.) London: HMSO, 1981.

${ }^{6}$ Spielberger CD, Gorsuch RL, Luohere RE. State-trait anxiety inventory. Palo Alto, California: Consulting Psychologists Press, 1970.

7 Nelder JA, Wedderburn RWM. Generalised linear models. Fournal of the Royal Statistics Society $1972 ; 135$, series A:370-84.

${ }^{8}$ Nye NH. Statistical package for the social sciences. 2nd ed. New York: McGraw-Hill, 1975.

${ }^{9}$ Butler NR, Alberman ED, Perinatal problems: the second report of the 1958 British perinatal mortality survey. Edinburgh: Livingstone, 1969.

${ }^{10} \mathrm{Cobb}$ S. A model for life-events and their consequences. In: Dohrenwend BS, Dohrenwend BP, eds. Stressful life-events: their nature and effects. New York: Wiley, 1974:151-6.

${ }^{11}$ Ashwell M, North WR, Meade TW. Social class, smoking and obesity. Br Med f 1978;ii:1466-7.

12 Brown GW, Harris T. Social origins of depression. London: Tavistock, 1978.

${ }^{13}$ Oakley A, Macfarlane A, Chalmers I. Social class, stress and reproduction. In: Rees AR, Purcell $\mathrm{H}$, eds. Disease and the environment. Chichester, Sussex: John Wright, 1982.

14 Simpson WJ. A preliminary report on cigarette smoking and the incidence of prematurity. Am $\mathcal{F}$ Obstet Gynecol $1957 ; 73: 808-15$.

15 D'Souza SW, Black P, Richards B. Smoking in pregnancy: associations with skinfold thickness, maternal weight gain, and fetal size at birth. Br Med f $1981 ; 282: 1661-3$.

${ }^{16}$ Copher DE, Huber CP. Heart rate response of the human fetus in induced maternal hypoxia. Am $\mathcal{F}$ Obstet Gynecol 1967;98:320-5.

17 Bontekoe EHM, Blacquiere JF, Naaktgeboren C, Dieleman SJ, Willems PPM. Influence of environmental disturbances on uterine motility during pregnancy and parturition in rabbit and sheep. Behavioural Processes 1977;2:41-73.

(Accepted 14 February 1984)
THE LIVER, AND ITS INFIRMITIES-If the liver be too hot, it usually proceeds from too much blood, and is known by redness of urine, the pulse is swift, the veins great and full, the spittle, mouth, and tongue, seem sweeter than they used to be: the cure is letting blood in the right arm. To cause the Liver well to digest-Take Oil of Wormwood, and so much Mastich in powder as will make it into a poultice, lay it warm to your right side. If the liver be stopped, the face will swell, and you shall be as sure to have a pain in your right side, as though you had it there already. For stoppage of the Liver-Use Garden-thyme in all your drinks and broaths, it will prevent stoppages before they come, and cure them after they are come. For the liverThe liver of a Hare dryed, and beaten into powder, cures all the diseases of the liver of man. (Nicholas Culpeper (1616-54) The Complete Herbal, 1850.)

WOMEN'S BREASTS, THEIR INFIRMITIES AND CURES-For sore BreastsTake a handful of Figs, and stamp them well till the kernels are broken, then temper them with a little fresh grease, and apply them to the breast as hot as the patient can endure; it will presently take away the anguish, and if the breast will break, it will break it, else it will cure it without breaking. An inward medicine for a sore BreastLet her drink either the juice or decoction of Vervain: it were fit that syrup were made of it to keep all the year. (Nicholas Culpeper (1616-54) The Complete Herbal, 1850.) 